\title{
Effect of Ionizing Radiation on Rat Parotid Gland
}

\author{
George BORAKS \\ Flávio Silva TAMPELINI \\ Kleber Fernando PEREIRA \\ Renato Paulo CHOPARD
}

Department of Anatomy, Institute of Biomedical Sciences, University of São Paulo, São Paulo, SP, Brazil

\begin{abstract}
A common side effect of radiotherapy used in the treatment of oral cancer is the occurrence of structural and physiological alterations of the salivary glands due to exposure to ionizing radiation, as demonstrated by conditions such as decreased salivary flow. The present study evaluated ultrastructural alterations in the parotid glands of rats receiving a fractionated dose (1,500-cGy) of radiation emitted by a Cesium-137 source and rats that were not subjected to ionizing radiation. After sacrifice, the parotid glands were removed and examined by transmission electron microscopy. Damage such as cytoplasmic vacuolization, dilatation of the endoplasmic reticulum and destruction of mitochondria, as well as damage to the cellular membrane of acinar cells, were observed. These findings lead to the conclusion that ionizing radiation promotes alterations in the glandular parenchyma, and that these alterations are directly related to the dose level of absorbed radiation. Certain phenomena that appear in the cytoplasm and nuclear material indicate that ionizing radiation causes acinar cell death (apoptosis).
\end{abstract}

Key Words: irradiation, parotid gland, transmission electron microscopy.

\section{INTRODUCTION}

The use of ionizing radiation as a therapeutic measure leads to significant morphofunctional alterations in the stomatognathic system, in both hard and soft tissues $(1,2)$. Ionizing radiation can produce detrimental changes in several classes of macromolecules found in cells.

In the case of proteins, the damage is the loss of lateral chains and alterations in secondary and tertiary structures, resulting in non-conformity of the protein molecules. In lipids, exposure to such radiation stimulates peroxidation of unsaturated fatty acids. Changes to nucleic acids may include damage to the base, base loss and breaks in one or both filaments of the DNA double helix. The effects of ionizing radiation are directly related not only to the type of the tissue receiving the radiation, but also to the absorbed radiation dose. Doses higher than 1000 cGy have been shown to promote alterations in the glandular parenchyma of irradiated rats as early as $6 \mathrm{~h}$ after irradiation (3).

The aim of this study was to evaluate the ultrastructural alterations that occur in parotid gland acinar cells of Wistar rats submitted to ionizing radiation.

\section{MATERIAL AND METHODS}

Ten adult male Wistar rats (Rattus novergicus) weighing between 250 and $350 \mathrm{~g}$ were allocated to 2 groups. Animals in GI (control; $n=5$ ) were not subjected to ionizing radiation, whereas those in GII (experimental; $n=5$ ) received a dose of 1,500-cGy fractionated in $750 \mathrm{cGy} /$ week. All animals were housed in a temperature-controlled environment $\left(21-23^{\circ} \mathrm{C}\right)$, maintained on a 12-h light/12-h dark cycle and given free access to food and water.

All animals were anesthetized with an intramuscular injection of a combination of ketamine hydrochloride (Ketalar ${ }^{\circledR}$; Parke Davis, Morris Plains, NJ, USA; 35 $\mathrm{mg} / \mathrm{kg}$ ), xylazine hydrochloride (Rompum ${ }^{\circledR}$; Bayer do

Correspondence: Prof. Dr. Renato Paulo Chopard, Departmento de Anatomia, Instituto de Ciências Biomédicas, Universidade de São Paulo, Avenida Lineu Prestes, 2415, Cidade Universitária, 05508-900 São Paulo, SP, Brasil. Tel: +55-11-3091-7326. e-mail: rchopard@usp.br 
Brasil S/A, São Paulo, SP, Brazil; $5.0 \mathrm{mg} / \mathrm{kg}$ ) and acepromazine (Acepran ${ }^{\circledR}$; Univet, São Paulo, SP, Brazil; $0.75 \mathrm{mg} / \mathrm{kg}$ ). Subsequently, study animals were exposed to gamma radiation emitted from a Cesium-137 radioactive source positioned at a distance of $20 \mathrm{~cm}$ from skin surface. A total dose of 1,500-cGy was used fractionated in $750 \mathrm{cGy} /$ week. During the procedure, the animals received radioprotection by means of a rectangular lead shelter (30-cm long, 20-cm deep and 5$\mathrm{cm}$ thick), leaving only the head and neck exposed and allowing approximately $3 \%$ of the total radiation dose to be directed to that region.

Immediately after exposure to the second fractioned dose of radiation, study and control animals were sacrificed by ketamine overdose and had the parotid glands removed. In preparation for examination by transmission electron microscopy (TEM), the glands were fixed in glutaraldehyde solution $(2.5 \%)$, fixed again in uranyl acetate $(0.5 \%)$, dehydrated, embedded in resin, cut into semi-thin and ultra-thin longitudinal sections, and examined with a transmission electron microscope (JEOL 1010; Jeol, Tokyo, Japan).

\section{RESULTS}

Figures $1 \mathrm{~A}-\mathrm{C}$ and $2 \mathrm{~A}-\mathrm{C}$ present TEM micrographs of GI and GII animals, respectively.

In the ultrastructural analysis, the acinar cells of the parotid glands from GII animals showed various alterations in the cytoplasmic organelles. Similarly, the granular endoplasmic reticula in the parotid glands from GI animals were rectangular and dense (Fig. 1A), whereas those in GII samples presented some expanded portions (Fig. 2B).

The mitochondrias in GI samples were of various sizes and morphology, but maintained the parallel aspect of the outer membrane, and dense areas of chromatin was observed at the periphery of the nucleus (Fig. 1B). In GII samples, in addition to intramitochondrial vacuolization, there was complete disruption of the outer mitochondrial membrane, suggesting degeneration of the organelle (Fig. 2C).

In the acinar cells of GII animals, widely dispersed cytoplasmic vacuolization was observed. In some cases, this vacuolization displaced the nucleus from its original position (Fig. 2A).

Intercellular unions, characterized by desmosomes and interdigitation, were also evaluated. In GI samples, the integrity of the desmosomes was preserved (Fig. 1C), in the same way as it was in samples from GII animals (Fig. 2C).

\section{DISCUSSION}

This study evaluated comparatively the effects resulting from exposing Wistar rats to a radiation dose
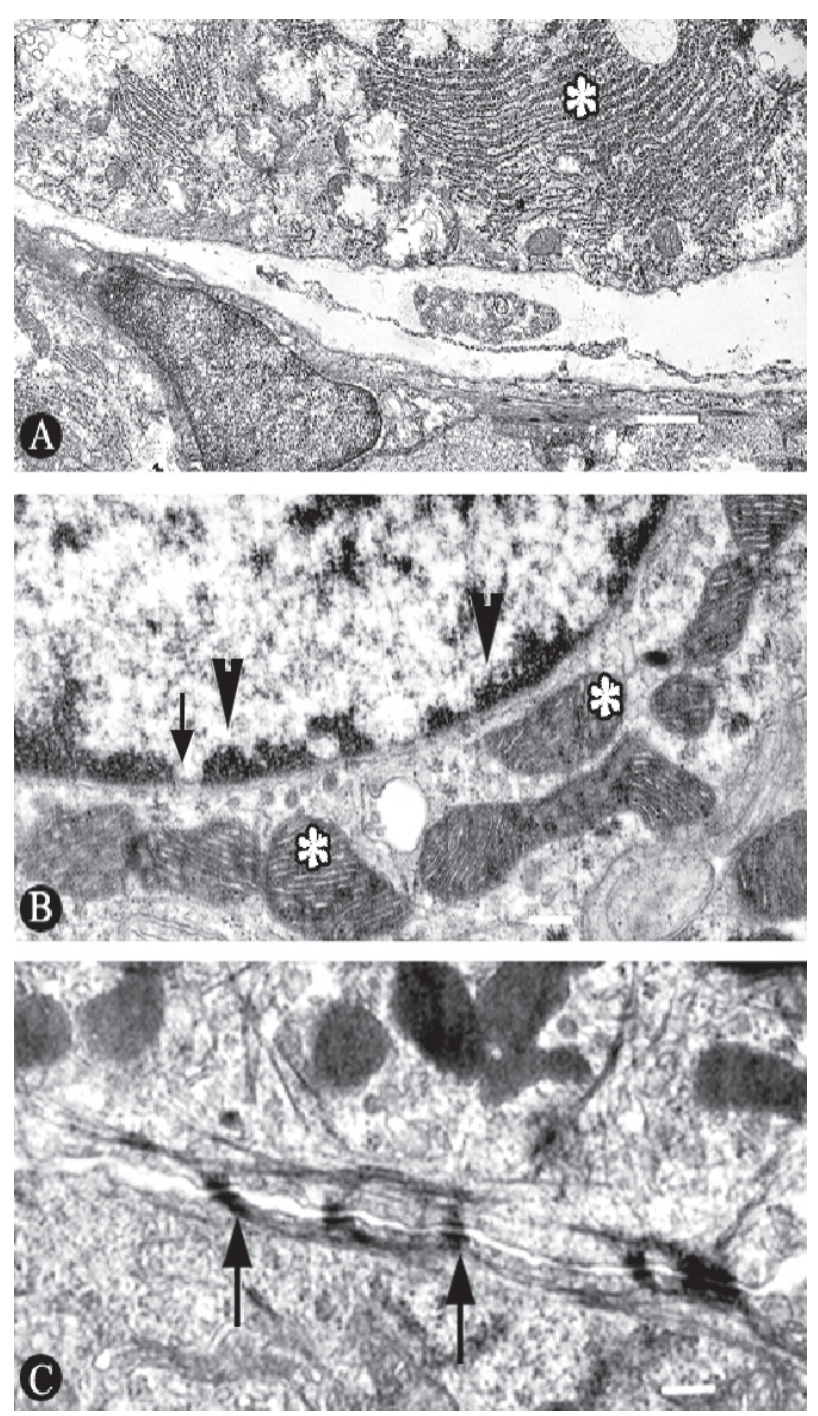

Figure 1. TEM micrographs of GI animals. A: Granular endoplasmic reticulum with an irregular, condensed aspect $(*)$ $(\times 12,000)$; B: Condensed chromatin (arrow) in the periphery of the nucleus of the cells (arrowheads) and mitochondria presenting parallelism of its crests and varied contour morphology $(*)$ $(\times 40,000)$; C: Intact desmosomes representing the intercellular unions (arrows) $(\times 50,000)$. 
of 1,500 cGy, fractionated to $750 \mathrm{cGy} /$ week.

The cytoplasmic vacuolization seen in samples from irradiated animals confirms data from previous studies (4-8). Some authors have observed that the expansion of the endoplasmic reticulum is associated to the cellular status that precedes apoptosis (4,9-15). In
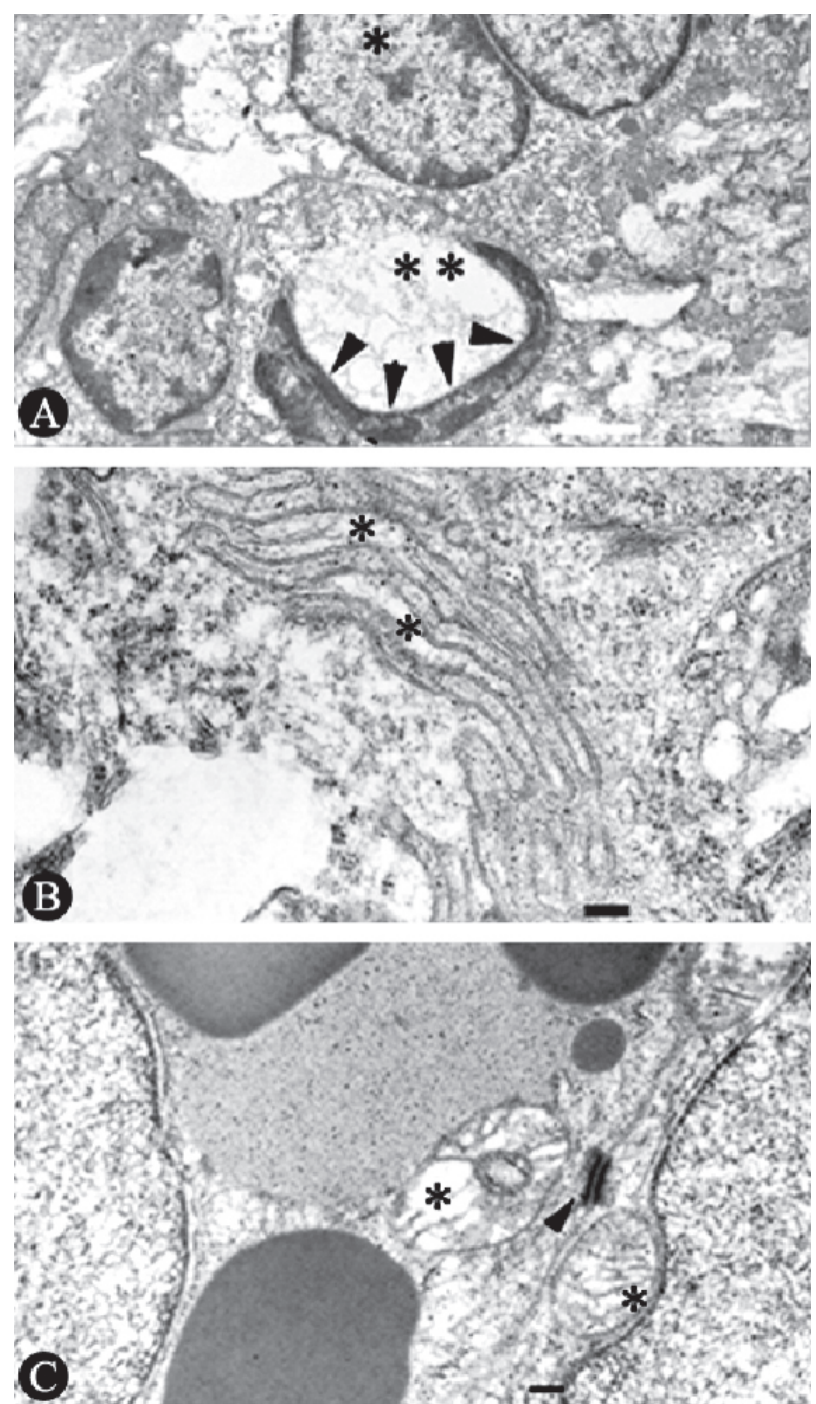

Figure 2. TEM micrographs of GI animals. A: Cytoplasmatic vacuolizations dispersed among the acinar cells of the irradiated animals. (**). In some cases, the cytoplasmatic vacuolization displaced the nucleus from its original position (arrowheads) $(\times 8,000)$; B: dilations of the granular endoplasmic reticulum $(*)$ $(\times 40,000)$; C: intercellular union preserved through the integrity of the desmosomes (arrowhead). It was also possible to observe the presence of destruction of the crests and intra-mitochondrial vacuolization $(*)(\times 40,000)$. accordance with these findings, areas of circular or concentric expansion in the endoplasmic reticula of irradiated animals were observed in this study. In general, this expansion is related to compression of the nuclear material. These widely dispersed intranuclear alterations may be attributed to the effect of the ionizing radiation. This explains the decreased expression of PCNA in the nuclei of irradiated acinar cells, as found by Takahashi et al. (12).

The cell membrane also presented signs of disruption. Based on the findings of Sesso et al. (14), this disruption is characteristic of the cellular stage that precedes apoptosis, since the loss of the outer nuclear membrane occurs right before apoptosis.

In samples from irradiated animals (GII), there was a disruption of the internal mitochondrial membrane and presence of vacuolization, as well as displacement of the outer mitochondrial membrane. Electron-dense granules were also observed in the mitochondrial interior, representing the effective loss of integrity of the mitochondrial membrane and leading to degeneration of the organelle and cell death. These findings support those from previous studies $(5,10,11,14,16-19)$.

Based on the employed methodology and the obtained results, it may be concluded that 1,500-cGy fractionated doses of ionizing radiation significantly altered acinar cells in rat parotid glands, as well as the serous acinar cells found at the interface, eventually leading to apoptosis.

\section{RESUMO}

Um efeito colateral comum da radioterapia usada no tratamento de câncer na cavidade oral é a ocorrência de alterações estruturais e fisiológicas sobre as glândulas salivares por exposição à radiação ionizante, como demonstrada em situações com decréscimo do fluxo salivar. O presente estudo teve por objetivo avaliar as alterações ultra-estruturais de glândulas parótidas de ratos que receberam uma dose fracionada ( 1500 - cGy) de radiação emitida por uma fonte de Césio 137 e ratos que não receberam a radiação ionizante. Após o sacrifício, as glândulas parótidas foram removidas e examinadas por microscopia eletrônica de transmissão. Lesões das organelas citoplasmáticas, como dilatação do retículo endoplasmático, destruição das mitocôndrias e formação das vacuolizações citoplasmáticas, além de lesão da membrana celular das células acinares foram observadas. Portanto, a radiação ionizante promove alterações no parênquima glandular, o que está diretamente relacionado com a dose de radiação absorvida. Determinados fenômenos que surgem no citoplasma e material nuclear são indicadores de que a radiação ionizante leva a célula acinar a morte programada (apoptose). 


\section{REFERENCES}

1. Li J, Shan Z, Ou G, Liu X, Zhang C, Baum BJ, et al.. Structural and functional characteristics of irradiation damage to parotid glands in the miniature pig. Int $\mathbf{J}$ Radiat Oncol Biol Phys 2005;62:1510-1516.

2. Radfar L, Sirois DA. Structural and functional injury in minipig salivary glands following fractionated exposure to $70 \mathrm{~Gy}$ of ionizing radiation: an animal model for human radiationinduced salivary gland injury. Oral Surg Oral Med Oral Pathol Oral Radiol Endod 2003;96:267-274.

3. Vissink A, S-Gravenmade EJ, Ligeon EE, Konings AWT. A functional and chemical study of radiation effects on rat parotid and submandibular/sublingual glands. Radiat Res 1990;124:259-265

4. Sodicoff M, Pratt NE, Trepper P, Sholley MM, Hoffenberg S. Effects of $\mathrm{X}$-irradiation and the resultant inanition on amylase content of the rat parotid gland. Arch Oral Biol 1977;22:261-267.

5. Kim KH, Kim JY, Sung MW, Kim CW. The effect of pilocarpine and atropine administration on radiation-induced injury of rat submandibular glands. Acta otolaryngol 1991;111:967-973

6. Stephens LC, Schultheiss TE, Price RE, Ang KK, Peters LJ. Radiation apoptosis of serous acinar cells of salivary and lacrimal glands. Cancer 1991;67:1539-1543.

7. Vissink A, S-Gravenmade EJ, Ligeon EE, Konings AWT. Effects of split-dose $\mathrm{X}$ irradiation on rat salivary gland function. Radiat Res 1991;127:52-57.

8. Peter B, Van Waarde MAWH, Vissink A, S-Gravenmade EJ, Konings AWT. Radiation-induced cell proliferation in the parotid and submandibular gland of the rat. Radiat Res 1994;140:257-265

9. Chomette G, Auriol M, Vaillant JM, Bertrand JCh, Chenal Ch. Effects of irradiation on the submandibular gland of the rat. Virchows Archiv 1981;391:291-299.
10. El-Mofty SK, Kahn AJ. Early membrane injury in lethally irradiated salivary gland cells. Int J Oncol Radiat Biol Phys 1981;39:55-62.

11. Vissink A, Kalicharan D, S-Gravenmade EJ, Jongeblord WL, Ligeon EE, Nieuwenhuis P, et al.. Acute irradiation effects on morphology and function of rat submandibular glands. J Oral Pathol Med 1991;20:449-456.

12. Takahashi S, Nakamura S, Suzuki R, Islam N, Domon T, Yamamoto $\mathrm{T}$, et al.. Apoptosis and mitosis of parenchymal cells in the duct-ligated rat submandibular gland. Tissue Cell 2000;32:457-463.

13. Takahashi S, Shinzato K, Nakamura S, Domon T, Yamamoto $\mathrm{T}$, Wakita M. Cell death and cell proliferation in the regeneration of atrophied rat submandibular glands after duct ligation. J Oral Pathol Med 2004;33:23-29.

14. Sesso A, Fujiwara DT, Jaeger M, Jaeger R, Li TC, Monteiro MMT, et al.. Structural elements common to mitosis and apoptosis. Cell Tissue 1999;3:357-371.

15. Takahashi S, Nakamura S, Domon T, Yamamoto $T$, Wakita M. Active participation of apoptosis and mitosis in sublingual gland regeneration of the rat following release from duct ligation. J Mol Histol 2005;36:199-205.

16. Riva A, Riva-testa F. Fine structure of acinar cells of human parotid gland. Anat Rec 1973;176:149-166.

17. Norberg LE, Lundquist PG. Aspects of salivary gland radiosensitivity: effects of sialagogues and irradiation. Arch Otorhinolaryngol 1989;246:200-204.

18. Kohn WG, Grossman E, Fox PC, Armando I, Goldstein DS, Baum BJ. Effect of ionizing radiation on sympathetic nerve function in rat parotid glands. J Oral Pathol Med 1992;21:134-137.

19. Tandler B, Pinkstaff CA, Nagato T, Phillips CJ. Giant secretory granules in the ducts of the parotid and submandibular glands of the slow loris. Cell Tissue 1996;28:321-329.

Accepted July 2, 2004 